\title{
Defects in insulin binding and receptor kinase in cells from a woman with type $A$ insulin resistance and from her family
}

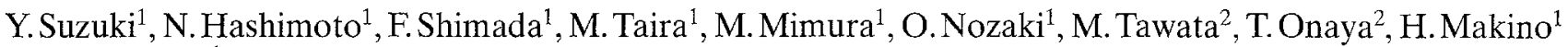 \\ and S. Yoshida ${ }^{1}$ \\ ${ }^{1}$ Second Department of Internal Medicine, Chiba University School of Medicine, Chiba \\ Third Department of Internal Medicine, University of Yamanashi Medical School, Yamanashi, Japan
}

\begin{abstract}
Summary. Defects in insulin receptor function lead to impairment of the insulin response. We treated a patient with the typical phenotype of type A syndrome of insulin resistance whose insulin receptor seemed to lack the transmembrane region and cytoplasmic domain. Hyperinsulinaemia and resistance to exogenous insulin were evident, and insulin binding to cells and uptake of 2-deoxyglucose into fibroblasts were greatly decreased. Molecular weight of the $\alpha$-subunit of the insulin receptor was normal, but autophosphorylation and kinase activity were impaired. In the pedigree analysis, defects in insulin binding were also observed in the mother, maternal grandfather and two maternal aunts, corresponding with the abnormality of the insulin receptor gene and mild insulin resistance. In the mother, much the same kinase
\end{abstract}

defects as were seen in the patient became evident. However, no relatives had clinical symptoms similar to those seen in the patient. In the father there was a mild insulin resistance in the glucose clamp study and a borderline impaired glucose tolerance. Although insulin binding to cells was normal in the father, both autophosphorylation and kinase activity were reduced. Our findings suggest that insulin resistance in the patient may be caused by the defects in insulin receptor kinase activity as well as by a reduction in insulin binding activity.

Key words: Insulin receptor, type A syndrome of insulin resistance, insulin binding, autophosphorylation, kinase activity.
The action of insulin at the cellular level is initiated by insulin binding to its receptor, with which the kinase is activated [1]. These events result in phosphorylation of the $\beta$ subunit on the tyrosine residues, and in an increase in kinase activity toward exogenous substrates. Therefore, a defect in insulin binding and/or receptor kinase activity is closely linked to impairment of insulin action at the cellular level.

Type A syndrome of insulin resistance is characterized by hyperinsulinaemia, resistance to exogenous insulin, acanthosis nigricans, polycystic ovaries and hyperandrogenism [2]. The pathogenesis of these disorders has not been clarified but alterations in the insulin receptor have been noted on both freshly isolated and cultured cells from these patients. This would suggest that a primary defect at the cellular level exists in these patients. In most patients with type A syndrome of insulin resistance, there is a decrease in the kinase activity in proportion to a decrease in receptor number [3-5]. In some patients, however, there is a decrease in kinase activity without alteration in insulin binding [4-7]. The complementary DNA for the insulin receptor was cloned $[8,9]$, and genetic defects in these patients were examined by analysing the insulin receptor gene [10-16]. The deletion in the ATP binding site of the tyrosine kinase domain of the insulin receptor gene in patients with type $\mathrm{A}$ variant syndrome of insulin resistance was found to result in a decrease in kinase activity [13].

In the present report, we describe our findings in a patient with type A insulin resistance with acanthosis nigricans in whom the insulin receptor gene was missing the 14 th exon coding outside of the cell membrane in the $\beta$ subunit [17]. We investigated this pedigree clinically as well as biochemically and analyses of the binding and kinase activities of the insulin receptor were made with erythrocytes, cultured fibroblasts and Epstein-Barr (EB) virus transformed lymphocytes from the patient and her family. We found that the phenotypically normal relatives as well as the proband had the same defects in insulin binding and insulin-stimulated kinase activity. These results suggest that other genetic factors may be necessary for onset of insulin resistant diabetes in this patient. 


\section{Subjects, materials and methods}

\section{The patient and her family}

The proband was a 16-year-old Japanese girl, $156 \mathrm{~cm}$ tall, weighing $76 \mathrm{~kg}$. Her physical appearance was considered to be typical of type $A$ insulin resistance: acanthosis nigricans and hirsutism. In 1984, at the age of 12 the patient herself noted skin pigmentation on her neck, and hirsutism. The next year she was referred to the Yamanashi Medical School Hospital because of acanthosis nigricans. At this time she had a normal glucose tolerance but a marked hyperinsulinaemia (serum insulin level: fasting $68 \mathrm{mU} / \mathrm{l}, 2 \mathrm{~h} 1486 \mathrm{mU} / \mathrm{l}$ ). In 1988 , at the age of 16 she was referred to the Chiba Medical School Hospital for an analysis of the insulin resistance. Physical examinations revealed an obese, hirsute girl. Acanthosis nigricans was present on the neck, in the axilla and the inguinal region. During the past three years she gained about $10 \mathrm{~kg}$ and the oral glucose tolerance test showed an obvious diabetic pattern. Fasting plasma glucose level was $11.2 \mathrm{mmol} / \mathrm{l}$ and the $\mathrm{Hb} \mathrm{A}_{\text {Ic }} 8.8 \%$. Hyperinsulinaemia in the basal state (47-81 mU/l) was evident, but the response of insulin secretion after glucose loading was markedly decreased $(2 \mathrm{~h}$ $124 \mathrm{mU} / \mathrm{l}$ ) as compared with previously obtained data. After being put on dietary restrictions she has lost weight and as a result, both glucose tolerance and the response of insulin have improved, yet the fasting hyperinsulinaemia remains (fasting $59 \mathrm{mU} / \mathrm{l}, 2 \mathrm{~h} 720 \mathrm{mU} / \mathrm{l}$ ). An intravenous insulin tolerance test using $0.1 \mathrm{U} / \mathrm{kg}$ body weight of Actrapid human insulin showed a resistance to exogenous insulin (maximal response $47 \%$ ). In the euglycaemic glucose clamp study, she had a marked insulin resistance [glucose disposal rate (GDR) $2.0 \mathrm{mg} \cdot \mathrm{kg}^{-1} \cdot \mathrm{min}^{-1}$ vs $9.3 \pm 1.6 \mathrm{mg} \cdot \mathrm{kg}^{-1} \cdot \mathrm{min}^{-1}$ in control subjects]. Serum insulin concentrations during the clamp study were $61.0 \mathrm{mU} / 1$ at the basal level and $150.8 \mathrm{mU} / \mathrm{l}$ in the steady state, compared with $8.2 \pm 2.9 \mathrm{mU} / 1$ and $76.4 \pm 13.8 \mathrm{mU} / 1$, respectively in control subjects. Insulin antagonistic hormones such as glucagon, growth hormone and glucocorticoids were at normal levels. Testosterone in both urine and plasma showed moderately elevated levels. Anti-insulin or anti-insulin receptor antibody was not detected. She began to menstruate at the age of 15 but her periods were irregular. The gynaecogram showed no enlarged ovaries consistent with polycystic ovary syndrome.

In the family study, the mother, the father and one of two maternal aunts had a borderline impaired glucose tolerance. In the paternal grandfather, there was a diabetic pattern. The paternal grandmother and maternal grandparents had an impaired glucose tolerance. All other relatives examined had a normal glucose tolerance. The mother, two maternal aunts and maternal grandfather had a tendency toward a hyperinsulinaemia during glucose loading. Both the mother and the father had mild insulin resistance in the glucose clamp study (GDR $6.6 \mathrm{mg} \cdot \mathrm{kg}^{-1} \cdot \mathrm{min}^{-1}$ and $4.8 \mathrm{mg} \cdot \mathrm{kg}^{-1} \cdot \mathrm{min}^{-1}$, respectively). None of the relatives except for the proband had either acanthosis nigricans or hirsutism. There was no consanguinity in her parents, and they were the real biological parents of the proband.

\section{Materials}

A monoclonal anti-insulin receptor antibody (2G7) was a generous gift from Dr. R. A. Roth (Stanford University, Calif., USA). Monocomponent porcine insulin was kindly provided by Novo Industries (Bagsvaerd, Denmark). Tyr-A14 labelled [ $\left.{ }^{125} \mathrm{I}\right]$ porcine insulin $(2200 \mathrm{Ci} / \mathrm{mmol}), 2-\left[1,2{ }^{3} \mathrm{H}\right]$-deoxy-D-glucose $(30.2 \mathrm{Ci} / \mathrm{mmol})$ and $[\gamma-$ $\left.{ }^{32} \mathrm{P}\right] \mathrm{ATP}(6000 \mathrm{Ci} / \mathrm{mmol})$ were obtained from New England Nuclear (Boston, Mass., USA). Tyr-B26 labelled $\left.{ }^{[25} \mathrm{I}\right]$ human insulin $(2000 \mathrm{Ci} / \mathrm{mmol}$ ) was from Amersham Laboratories (Buckinghamshire, UK). Synthetic peptide poly [GIu, Tyr (4:1)] were from Sigma Chemical Company (St. Louis, Mo., USA). All other reagents were of the best grade available.

Cells. Skin fibroblasts were obtained from the patient, her parents and non-diabetic control subjects by biopsy of the volar forearm.
Cells were maintained in the culture dishes with Eagle's minimal essential medium containing $10 \%$ fetal calf serum (FCS) at $37^{\circ} \mathrm{C}$. The cells were trypsinized, divided and used between the fifth and twelfth passages.

Mononuclear cells were collected by centrifuging the heparinized blood with Lymphoprep. After washing three times with culture medium, B-lymphocytes were separated by agglutinating T-lymphocytes with sheep erythrocytes. Cells were suspended at a density of $5 \times 10^{6}$ cells $/ \mathrm{ml}$ in culture medium supplemented with $20 \%$ FCS. After incubation for $1 \mathrm{~h}$ at $37^{\circ} \mathrm{C}$ with $\mathrm{EB}$ virus, the fresh medium was added and the cells were cultured at $37^{\circ} \mathrm{C}$ in an atmosphere of $5 \% \mathrm{CO}_{2}$. The transformed lymphocytes began to proliferate after 2 to 5 weeks in culture medium containing $20 \%$ FCS.

Insulin binding studies. Studies of insulin binding to erythrocytes or the cultured fibroblasts were performed as described elsewhere [18].

Lectin purification of the insulin receptors. Lectin-purified insulin receptors were obtained from the cultured fibroblasts and the transformed lymphocytes, as described by Grigorescue et al. [19]. Insulin binding to the partially purified insulin receptors was performed as described [20], with some modification.

Uptake of 2-Deoxyglucose. 2-Deoxyglucose (2-DOG) uptake into the cultured fibroblasts was assayed as described elsewhere [18].

Autophosphorylation of the insulin receptor. Autophosphorylation of the partially purified insulin receptors from the cultured fibroblasts and the transformed lymphocytes was carried out, as described previously [13].

Tyrosine kinase assay. The assay was performed by using the lectinpurified insulin receptor preparations from the transformed lymphocytes, as described previously [13].

Cross-linking of $\left[{ }^{125} I\right]$ insulin to the lectin-purified insulin receptors. $\left[{ }^{125} \mathrm{I}\right]$ insulin was covalently cross-linked to the purified insulin receptors from the transformed lymphocytes, according to Pilch and Czech [22].

\section{Statistical analysis}

Statistical analysis was carried out using the unpaired Student's $t$-test.

\section{Results}

\section{Insulin binding studies}

Binding of labelled and unlabelled insulin to erythrocytes from the proband and her family is shown in Figure 1a. Insulin binding was markedly decreased in the proband and in the mother. Maximal specific binding of $\left[{ }^{125} \Gamma\right] \mathrm{in}$ sulin at the lowest insulin concentration $(0.03 \mathrm{nmol} / \mathrm{l})$ was $2.9 \%$ in the proband and $3.6 \%$ in the mother, compared with $7.9 \pm 1.4 \%$ in control subjects. Scatchard analysis of the specific binding revealed a decreased receptor number but a normal receptor affinity for insulin. Insulin binding to erythrocytes from the father and the sister was in a normal range (9.3\% and $9.8 \%$ ). Two maternal aunts also showed a decrease in insulin binding $(3.7 \%$ and $3.2 \%$ ) and in the maternal grandfather there was a slight decrease in insulin binding $(6.0 \%)$. The maternal grandmother and uncle had a normal insulin binding $(7.7 \%$ and $12.1 \%$ ). 

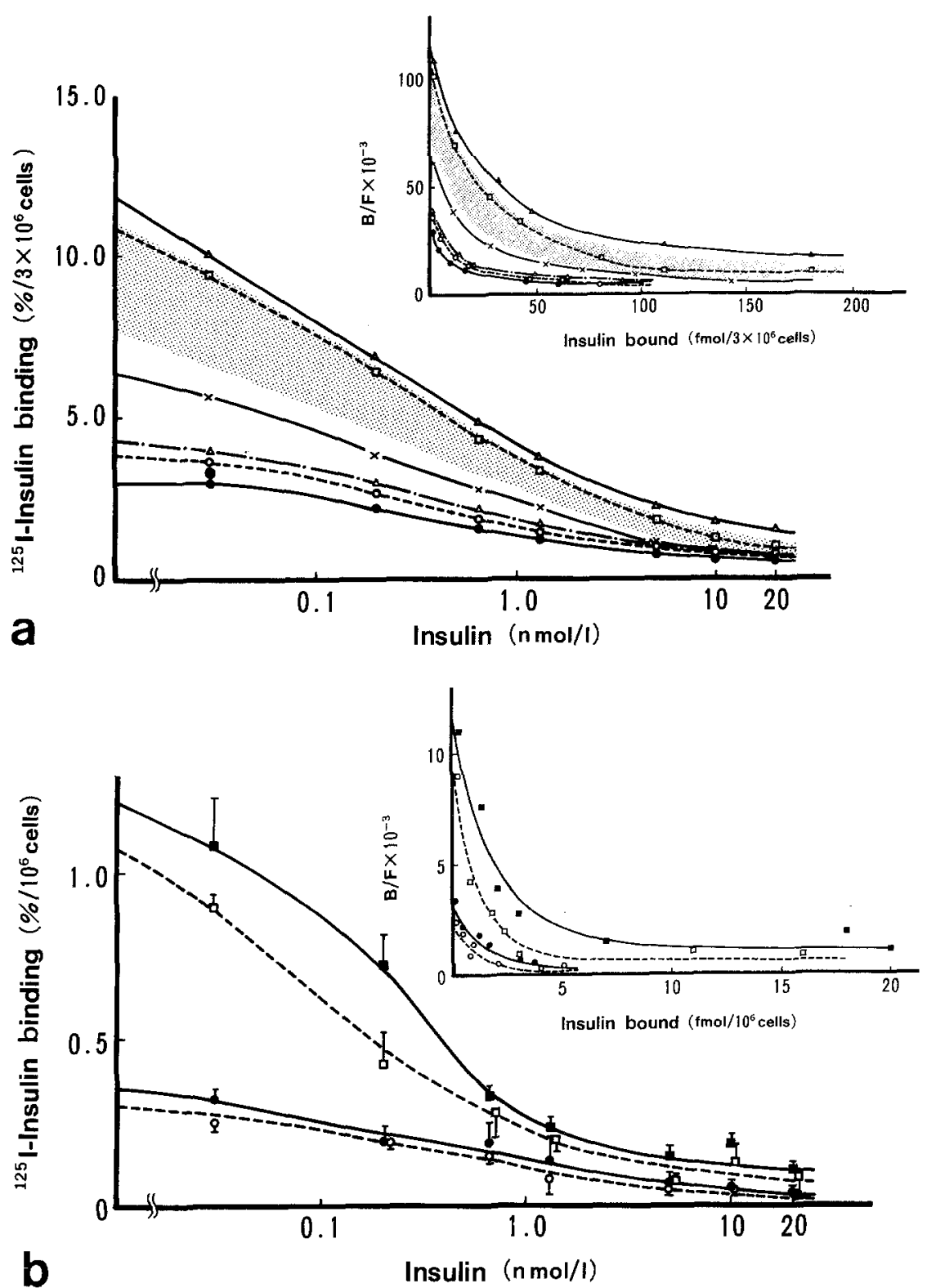

Fig. 1. a Insulin binding to erythrocytes. The proband $(\bullet)$, her mother $(\mathrm{O}--\mathrm{O})$, her father $(\square--\square)$, her sister $(\triangle \triangle)$, maternal grandfather $(x-x)$ and two maternal aunts $(\triangle--\Delta$, (0). The shaded area indicates the mean \pm SD in the normal control subjects $(n=21)$. Erythrocytes were incubated with A-14 labelled [ $\left.{ }^{[25} \mathrm{I}\right]$ insulin $(0.03 \mathrm{nmol} / \mathrm{l})$ and various concentrations of porcine insulin at $15^{\circ} \mathrm{C}$ for $210 \mathrm{~min}$. After incubation bound insulin was separated with a Beckman Microfuge $B$ and counted with a gamma counter. The insert shows a Scatchard plot. b Insulin binding to the cultured fibroblasts. Cells from the proband $(\bullet)$, her mother (O---০), her father $(\square-\cdots)$ and control subjects (-) were incubated with A-14 labelled $\left[{ }^{125} \mathrm{I}\right]$ insulin $(0.03 \mathrm{nmol} / \mathrm{l})$ and various concentrations of unlabelled insulin. The results are expressed as the mean \pm SEM of percent insulin bound $/ 10^{6}$ cells in three to six separate experiments. Six different normal control subjects were used for this study. The insert shows a Scatchard plot
Figure 1b shows competition curves and Scatchard plots for specific binding of $\left[{ }^{125} \mathrm{I}\right]$ insulin to skin fibroblasts from the proband, her parents and control subjects. In agreement with the result of erythrocytes, insulin binding to fibroblasts from the proband and her mother was decreased $(0.33 \pm 0.02 \%$ and $0.28 \pm 0.03 \%)$, compared with findings in control subjects (1.08 \pm $0.14 \%$ ). Scatchard analysis suggested that the decreased insulin binding was due to decreased numbers of receptors.

We also examined insulin binding to the transformed lymphocytes. Insulin binding to cells from the proband and her mother was remarkably decreased $(11.7 \%$ and $10.2 \%)$, compared with findings in control subjects $(28.4 \pm 4.6 \%$, mean \pm SEM, $n=7)$. Insulin binding in the father was normal $(23.0 \%)$. However, insulin binding to the lectin-purified receptors from the fibroblasts and the transformed lymphocytes in the father was as low as the values in the proband and the mother. These results remain to be elucidated.

\section{2-deoxyglucose (2-DOG) uptake in the cultured fibroblasts}

The effect of increased insulin concentrations on 2-DOG uptake was examined using the cultured fibroblasts. The basal 2-DOG uptake was $0.108 \pm 0.01 \mathrm{nmol} / \mathrm{min}$ per $100 \mu \mathrm{g}$ protein in the proband, $0.147 \pm 0.02$ in the mother and $0.172 \pm 0.02$ in control subjects, respectively. When the data were analysed as a percentage of the basal 2DOG uptake, the stimulation of insulin was decreased in the proband and in the mother, compared with findings in control subjects, as shown in Figure 2.

\section{Autophosphorylation of the lectin-purified insulin receptors}

Figure 3 shows autophosphorylation of the lectin-purified insulin receptors obtained from the cultured fibroblasts from the proband (a), the mother (b), the 


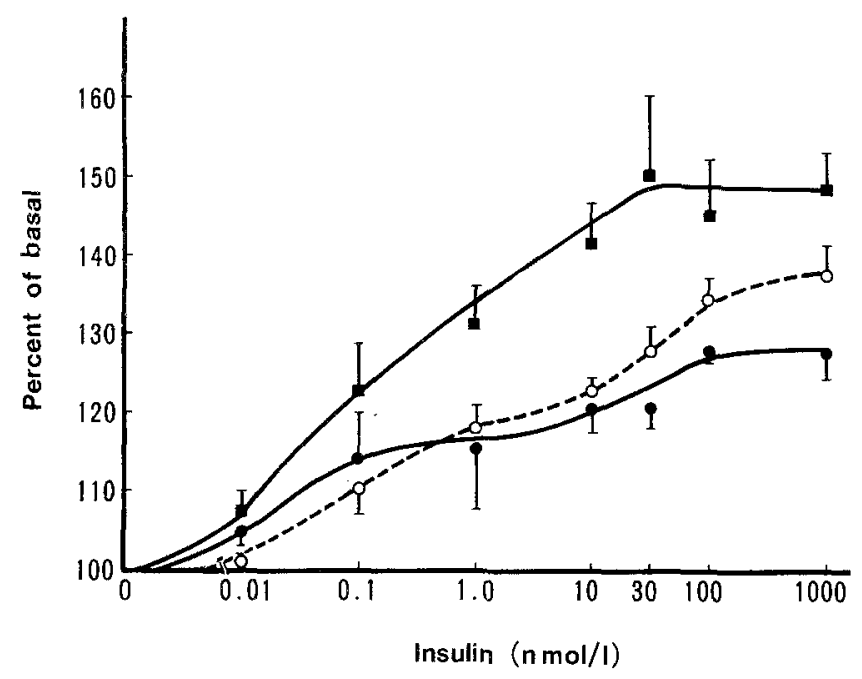

Fig. 2. Insulin stimulation of glucose uptake into the cultured fibroblasts. Uptake of 2 -deoxy $\left[{ }^{3} \mathrm{H}\right]$ glucose in cells from the proband $(-)$, her mother (O--O) and control subjects (-) was assayed after $120 \mathrm{~min}$ of incubation with indicated concentrations of insulin. The results are expressed as a percent stimulation of the basal value in fibroblasts that did not receive insulin, and represented as the mean \pm SEM in six separate experiments

father (c) and the normal control subjects. Increasing concentrations of insulin distinctly augmented the ${ }^{32} \mathrm{P}$ incorporation into the $95 \mathrm{kDa}$ protein which corresponded to the $\beta$-subunit. Stimulation of phosphorylation of the $\beta$ subunit at each insulin concentration was decreased in the proband, compared with findings in control subjects, despite equal amounts of binding capacity. Receptor autophosphorylation in the mother and the father was also decreased.

We examined receptor autophosphorylation with the lectin-purified receptor preparations from the transformed lymphocytes (Fig.4). The decrease in ${ }^{32} \mathrm{P}$ incorporation into the $\beta$-subunit, with and without insulin, was apparent in the mother and the father as well as in the proband, compared with findings in control subjects. The molecular weight of the phosphorylated $\beta$-subunit did not differ in all cells examined.

\section{Tyrosine kinase activity}

We studied the tyrosine kinase activity of the insulin receptor toward an exogenous substrate (Fig.5). Kinase activities in $\mathrm{EB}$ virus transformed lymphocytes from the proband, the mother, and the father were decreased in the case of both basal and insulin-stimulated $(1 \mu \mathrm{mol} / \mathrm{l})$ phosphorylation, in proportion to the decrease in autophosphorylation. The basal kinase activities were $6.3 \pm 1.1 \mathrm{pmol} \cdot \mathrm{mg}^{-1}$ polyglu: tyr $15 \mathrm{~min}^{-1}$ in the proband, $10.1 \pm 1.3$ in the mother and $9.2 \pm 2.1$ in the father, compared with a value of $13.1 \pm 2.6$ in control subjects, respectively. Basal and insulin-stimulated kinase activities were decreased by $51.9 \%$ and $56.6 \%$ in the proband, by $22.9 \%$ and $33.7 \%$ in the mother and by $29.8 \%$ and $32.6 \%$ in the father, compared with the results in control subjects, respectively. When the data obtained from the proband and her parents were expressed as a ratio of stimulated to basal kinase activities, the values were within the normal range. However, when expressed as increment in kinase activity stimulated by insulin (stimulated minus basal), the values were decreased compared with those in control subjects (data not shown).

\section{Cross-linking of insulin receptor}

As shown in Figure 6, $\left[{ }^{125} \mathrm{I}\right]$ insulin was cross-linked to the protein from the transformed lymphocytes with a molecular mass of approximately $135 \mathrm{kDa}$ which cor-

Fig.3a-c. Autophosphorylation of the insulin receptors from cultured fibroblasts from the proband (a), her mother (b) and her father (c), compared with findings in control subjects. Lectin-purified insulin receptors were preincubated without insulin (lane $A, D$ ) or with $1 \mathrm{nmol} / 1$ (lane $B, E$ ) or $1 \mu \mathrm{mol} /$ linsulin (lane $C, F$ ) at $4^{\circ} \mathrm{C}$ for $12 \mathrm{~h}$, and then incubated with $4.5 \mathrm{mmol} / 1 \mathrm{MnCl}_{2}$ and $10 \mu \mathrm{mol} / /\left[\gamma^{32} \mathrm{P}\right] \mathrm{ATP}$ $\left(40 \mu \mathrm{Ci} /\right.$ lane) for $15 \mathrm{~min}$ at $20^{\circ} \mathrm{C}$. After the addition of stopping solution, immunoprecipitation with anti-insulin receptor antibody (2G7) [21] was done, followed by electrophoresis on SDS-polyacrylamide gels under reducing conditions and autoradiography. Receptor concentrations were adjusted to the same insulin binding capacity as for each control subject (a: $3.0 \%, \mathbf{b :} 2.0 \%$ and $\mathbf{c} 2.0 \%$, respectively). Different control subjects were used in each experiment

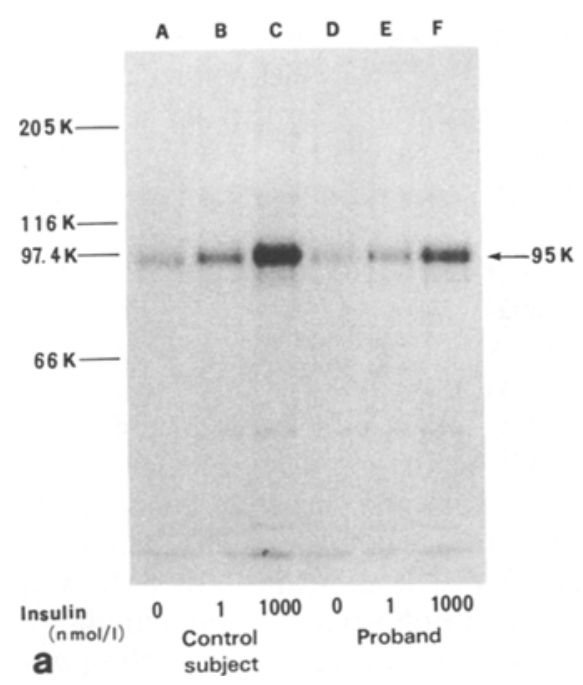

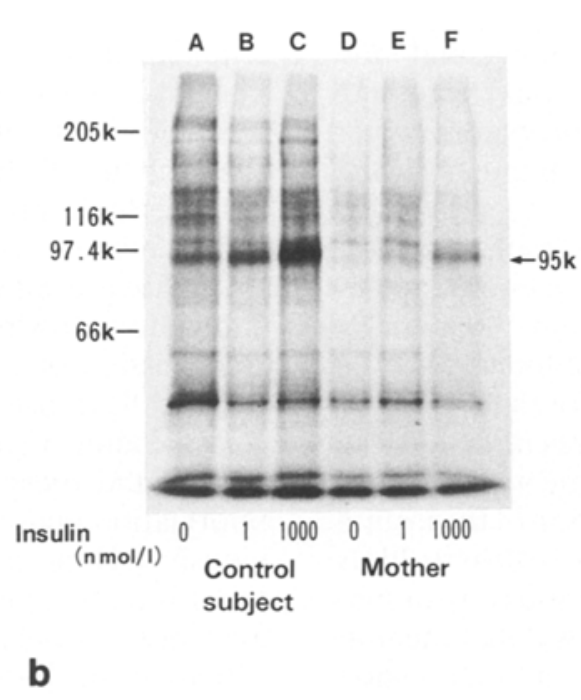

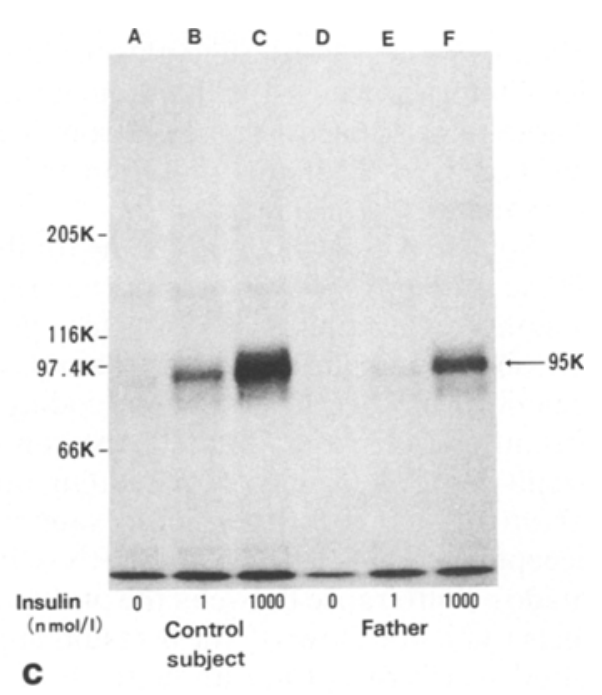




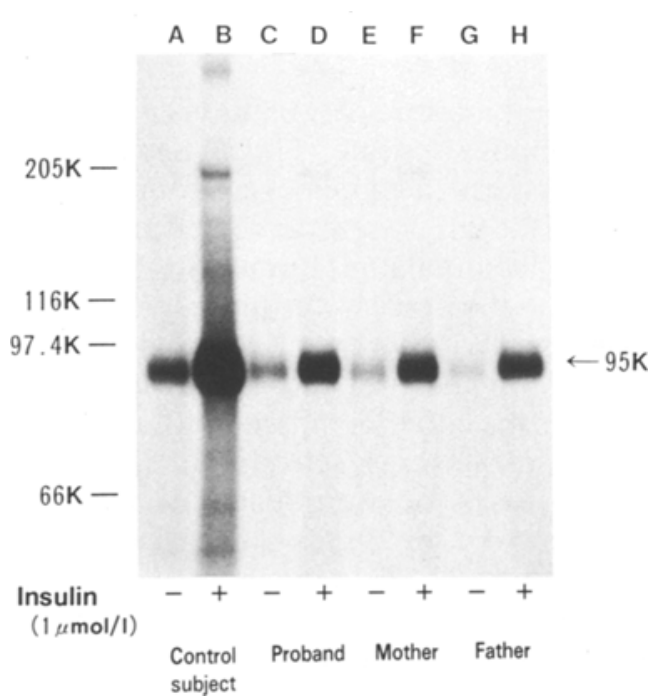

Fig.4. Autophosphorylation of the insulin receptors from EpsteinBarr virus transformed lymphocytes from control subject (lane $A, B$ ), the proband (lane $C, D$ ), her mother (lane $E, F$ ) and her father (lane $G, H$ ). Lectin-purified preparations were preincubated with or without $1 \mu \mathrm{mol} / \mathrm{l}$ insulin and then the autophosphorylation study was done, as described in the Figure 3 legend. The samples adjusted for equal amounts of insulin binding capacity (2.0\%) were applied to all lanes. Amounts of protein were $15 \mu \mathrm{g} / \mathrm{lane}$ in control subject, $40 \mu \mathrm{g} /$ lane in the proband, $50 \mu \mathrm{g} / \mathrm{lane}$ in the mother and $100 \mu \mathrm{g} /$ lane in the father, respectively

responded to the $\alpha$-subunit. The labelling was specific, since addition of $2.5 \mu \mathrm{mol} / 1$ unlabelled insulin prevented the cross-linking of [ $\left.{ }^{125} \mathrm{I}\right]$ insulin to the $135 \mathrm{kDa}$ protein. The molecular mass of the $\alpha$-subunit in the proband, the mother, the father and control subjects was the same.

\section{Discussion}

We treated a patient who was considered to have a typical type A syndrome of insulin resistance because of acanthosis nigricans, hirsutism and hyperinsulinaemia. There was a marked resistance to exogenous insulin and insulin binding to erythrocytes or the cultured cells was greatly decreased. Although her mother had an almost normal phenotype with borderline glucose intolerance and mild insulin resistance, insulin binding activity was decreased. These results suggest that cells from the proband and her mother have a genetic alteration in the number or the structure of the insulin receptor.

Southern blots of DNA coding for the insulin receptor of the proband showed an abnormal restriction fragment length polymorphism (RFLP). In a genomic analysis of the abnormal band from the proband, we found a partial deletion of insulin receptor gene coding for the $\beta$-subunit. Because of this deletion the 14th exon was removed, the result being alteration of the reading frame which caused a stop codon [17]. Furthermore, examination of the insulin receptor-mRNA level in total RNA by Northern blots made no difference between the proband and control subjects (data not shown). These results suggest that the mutated insulin receptor, without the transmembrane region

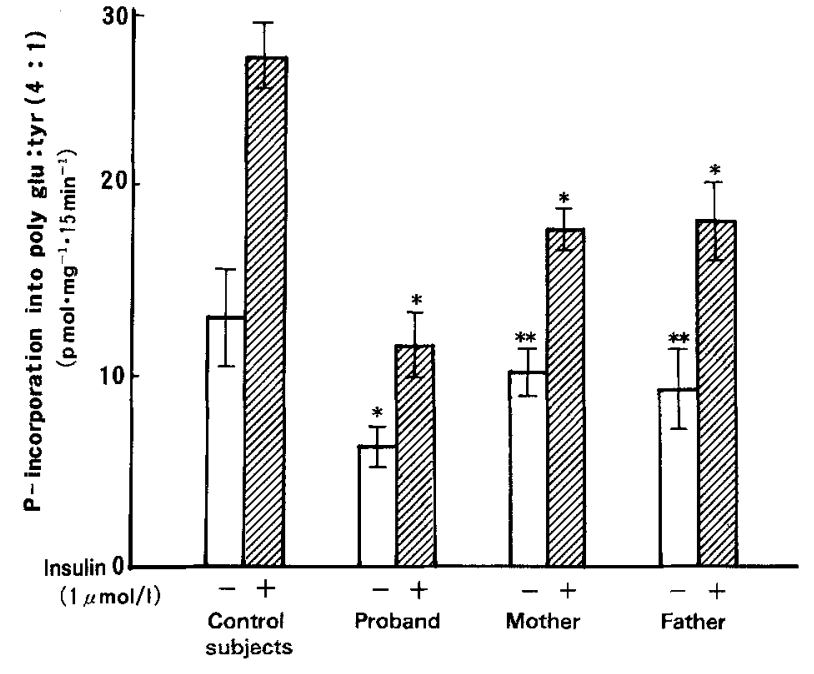

Fig.5. Tyrosine kinase activity in the insulin receptor. The lectinpurified insulin receptor preparations from Epstein-Barr virus transformed lymphocytes were incubated in the absence $(-)$ or presence (+) of $1 \mu \mathrm{mol} / 1$ insulin at $24^{\circ} \mathrm{C}$ for $60 \mathrm{~min}$. Receptor concentrations were adjusted to an equal binding capacity (4.0\%) for the proband, the mother, the father and control subjects. The phosphorylation of the synthetic peptide poly [Glu, Tyr (4:1)] was counted in a liquid scintillation counter. The results are expressed as pmol of phosphate per $\mathrm{mg}$ of the substrate per insulin binding activity ( $4.0 \%$ ) for $15 \mathrm{~min}$. The open bars represent the basal activity and the shaded bars the insulin-stimulated ${ }^{32} \mathrm{P}$ incorporation. The data are expressed as the mean $\pm S D$ in six separate experiments, using three different control subjects. ${ }^{*} p<0.01, * * p<0.05$

and cytoplasmic domain, may be produced. Recent studies using cells transfected with the truncated insulin receptor revealed that most of the entire extracellular domain of the receptor without transmembrane and cytoplasmic domain is secreted in culture medium, with a very small fraction remaining on the cell surface, and that the insulin receptor with only the $\alpha$-subunit is unstable [23]. Thus, the mutant receptors may be unstable and not be expressed on the cell membrane, the result being a reduction in the number of insulin receptors in cells from the proband. This abnormal RFLP was also noted in the mother, maternal grandfather and two maternal aunts, corresponding with reduced insulin binding. All apparently had a mild insulin resistance as deduced from the hyperinsulinaemia during glucose loading. However, none of the subjects showed the clinical symptoms similar to those seen in the proband. Therefore, the cause of the insulin resistant diabetes in the proband may not have been only a defect in insulin binding.

There are data supporting the hypothesis that insulinstimulated tyrosine kinase plays an important role in the transmission of insulin action [24-27]. Chinese hamster ovary cells transfected with the mutated $\beta$-subunit in the ATP binding region abolish insulin-stimulated glucose uptake and receptor kinase activity $[24,25]$. Autophosphorylation and kinase activity in the proband were obviously decreased, compared with findings in control subjects. Interestingly, both the mother and father showed evidence of a decreased autophosphorylation and kinase activity of the $\beta$-subunit. Hence, defects in autophospho- 


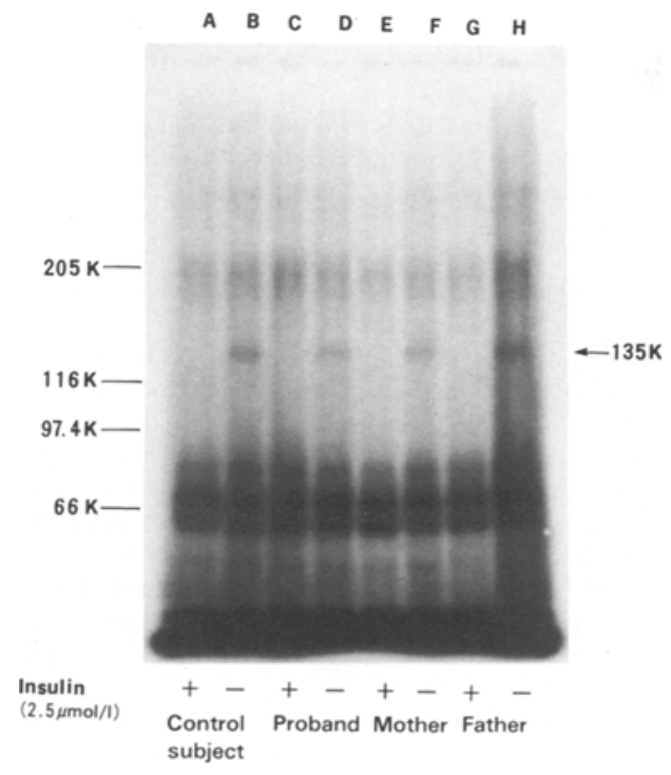

Fig.6. Affinity labelling of the insulin receptor in Epstein-Barr virus transformed lymphocytes from the control subject (lane $A, B$ ), the proband (lane $C, D$ ), the mother (lane $E, F$ ) and the father (lane $G, H$ ). The lectin-purified receptors from lymphocyte membrane were cross-linked to $B-26$ labelled [ $\left.{ }^{125} \mathrm{~T}\right]$ insulin with $2.5 \mu \mathrm{mol} / \mathrm{l}$ (lane $A, C, E, G$ ) or without (lane $B, D, F, H$ ) unlabelled insulin by disuccinimidyl suberate

rylation and kinase activity in the proband may be inherited from the parents and her insulin resistance may be caused by an impairment of kinase activity, in addition to a defect in insulin binding.

We reported details on the mechanism of the defect in kinase activity in a patient with type A variant syndrome of insulin resistance (IR-Chiba), at the genetic level [13]. The defect was due to a deletion in the insulin receptor gene downstream from the 17th exon, including the ATP binding site. Although insulin binding was normal in this patient, in others tyrosine kinase activity of the insulin receptor was decreased in proportion to a reduction in insulin binding [3-5]. In the case of leprechaunism, autophosphorylation was decreased despite the point mutation in the insulin receptor gene coding for the $\alpha$-subunit $[15,28,29]$. Our findings in the present study were consistent with these data.

However, it is not clear why autophosphorylation and kinase activity in the insulin receptors from cells of the mother were reduced. One possibility is that the mutant receptors may be unable to translocate to the cell membrane and the ones remaining in the cell were purified together with the normal receptors, with solubilization of the cell membrane and the subsequent affinity chromatography. Another possibility is that a small part of chimera receptors from the mutant receptor and the normal receptor may be expressed on the cell membrane. If so, these chimera receptors might reduce insulin binding and kinase activity.

The interesting point is that the proband's mother had neither an insulin resistant diabetes nor a fasting hyperinsulinaemia and yet did have defects in insulin binding and in kinase activity as seen in the proband. The following ex- planations may be possible regarding this discrepancy. First, Taira et al. reported that functions of the normal insulin receptor seem to be suppressed in the case of IRChiba where mutant receptors without the tyrosine kinase domain may be expressed on the cell surface [13]. But in the proband's mother, the mutant receptors seem to be littleexpressed on the cell surface. Thus, functions of the normal receptors would not be suppressed. Second, a moderate reduction of the insulin receptor as in the present case may lead to only a mild insulin resistance, in vivo, because of socalled "spare receptors". However, in fibroblasts of the mother, since the number of receptors was only a few thousand per cell, a reduction might cause insulin resistance, as seen in the proband. The mother and two aunts will probably develop diabetes, when factors such as aging, obesity and infection are added. The impaired glucose tolerance in the maternal grandfather may be related to age.

At least two explanations are feasible regarding the onset of diabetes in the proband. First, a compound heterozygote which contains two abnormal alleles of the insulin receptor genes may cause insulin resistance in the proband. One allele inherited from her mother caused a defect in insulin binding and another was from her father with regard to defects in autophosphorylation and kinase activity. Second, the acquired factors, especially obesity, may be closely related with onset of diabetes. She gained about $10 \mathrm{~kg}$ during three years and then the oral glucose tolerance test showed a marked diabetic pattern. Although insulin resistance and fasting hyperinsulinaemia were not altered, both glucose intolerance and insulin secretion improved when she lost weight while on dietary therapy. Thus, her diabetes was probably related to acquired and genetic defects. Insulin secretion and glucose tolerance improved with loss of body weight, as observed in subjects with Type 2 (non-insulin-dependent) diabetes.

We have described details of a patient with type A syndrome of insulin resistance accompanied by the mutant insulin receptor which caused decreased insulin binding and receptor kinase activity. We want to emphasize the following points: first, a genetic defect which causes a decrease in insulin binding is inherited from the maternal grandfather and from the mother. Second, onset of diabetes cannot be explained by this genetic defect alone because subjects with the same abnormality of the insulin receptor showed different clinical symptoms such as normal tolerance, impaired glucose tolerance and insulin resistant diabetes. Third, abnormality in the insulin receptor may exist even in the phenotypically normal subjects without glucose intolerance and fasting hyperinsulinaemia. Therefore, abnormality of the insulin receptor is probably present in some patients with Type 2 diabetes and even subjects with a normal phenotype.

Acknowledgements. We thank Dr. R.A. Roth (Department of Pharmacology, Stanford University) for the kind gift of monoclonal antibodies $2 \mathrm{G} 7$. We are indebted to Dr. K. Aida and Dr. K. Ohsawa for helpful assistance and to Ms. F. Watanabe for expert assistance and to M. Ohara for comments on the manuscript. This work was supported in part by Scientific Research Grants 63570523 from the Ministry of Education, Science and Culture, Japan and by a Research Grant from the Foundation for Growth Science in Japan and by a Research Grant from Asahi Life Foundation. 


\section{References}

1. Kasuga M, Karlsson FA, Kahn CR (1982) Insulin stimulates the phosphorylation of the 95,000 -dalton subunit of its own receptor. Science 215: 185-187

2. Kahn CR, Flier JS, Bar RS, Archer JA, Gorden P, Martin MM, Roth $\mathbf{J}(1976)$ The syndrome of insulin resistance and acanthosis nigricans. Insulin-receptor disorders in man. N Engl J Med 294: $739-745$

3. Grunberger G, Coni RJ, Taylor SI, Gorden P (1984) Tyrosine kinase activity of the insulin receptors of patients with type $\mathrm{A}$ extreme insulin resistance: studies with circulating mononuclear cells and cultured lymphocytes. J Clin Endocrinol Metab 59: $1152-1158$

4. Grigorescu F, Flier JS, Kahn CR (1986) Characterization of binding and phosphorylation defects of erythrocyte insulin receptors in the type A syndrome of insulin resistance. Diabetes 35: $127-138$

5. Grigorescu F, Herzberg V, King G, Meistas M, Elders J, Frazer J, Kahn CR (1987) Defects in insulin binding and autophosphorylation of erythrocyte insulin receptors in patients with syndrome of severe insulin resistance and their parents. J Clin Endocrinol Metab 64: 549-556

6. Grunberger G, Zick Y, Gorden P (1984) Defect in phosphorylation of cells from an insulin-resistant patient with normal insulin binding. Science 223: 932-934

7. Grigorescu F, Flier JS, Kahn CR (1984) Defect in insulin receptor phosphorylation in erythrocytes and fibroblasts associated with severe insulin resistance. J Biol Chem 259: 15003-15006

8. Ullrich A, Bell JR, Chen EY et al. (1985) Human insulin receptor and its relationship to the tyrosine kinase family of oncogenes. Nature 313: 756-761

9. Ebina Y, Ellis L, Jarnagin K et al. (1985) The human insulin receptor cDNA: the structural basis for hormone-activated transmembrane signaling. Cell 40: 747-758

10. Yoshimasa Y, Seino S, Whittaker J et al. (1988) Insulin-resistant diabetes due to a point mutation that prevents insulin proreceptor processing. Science 240: 784-787

11. Kadowaki T, Bevins CL, Cama A et al. (1988) Two mutant alleles of the insulin receptor gene in a patient with extreme insulin resistance. Science 240: 787-790

12. Moller DE, Flier JS (1988) Detection of an alteration in the insulin-receptor gene in a patient with insulin resistance, acanthosis nigricans, and the polycystic ovary syndrome (type A insulin resistance). N Engl J Med 319: 1526-1529

13. Taira M, Taira M, Hashimoto N et al. (1989) Human diabetes associated with a deletion of the tyrosine kinase domain of the insulin receptor. Science 245: 63-66

14. Odawara M, Kadowaki T, Yamamoto R et al. (1989) Human diabetes associated with a mutation in the tyrosine kinase domain of the insulin receptor. Science 245: 66-68

15. Klinkhamer MP, Groen NA, Zon GCM van der et al. (1989) A leucine-to-proline mutation in the insulin receptor in a family with insulin resistance. EMBO J 8: 2503-2507

16. Accili D, Frapier C, Mosthaf L et al. (1989) A mutation in the insulin receptor gene that impairs transport of the receptor to the plasma membrane and causes insulin-resistant diabetes. EMBO J 8:2509-2517
17. Shimada F, Taira M, Suzuki Y et al. (1990) Insulin resistant diabetes associated with a deletion of exon 14 of the insulin receptor gene. Lancet 335: 1179-1181

18. Nakamura F, Taira M, Hashimoto N, Makino H, Sasaki N (1989) Familial type $\mathrm{C}$ syndrome of insulin resistance and short stature with possible autosomal dominant transmission. Endocrinol Japon 36: 349-358

19. Grigorescu F, White MF, Kahn CR (1983) Insulin binding and insulin dependent phosphorylation of the insulin receptor solubilized from human erythrocytes. J Biol Chem 258: 13708-13716

20. Hedo JA, Harrison LC, Roth J (1981) Binding of insulin receptors to lectins: evidence for common carbohydrate determinants on several membrane receptors. Biochemistry 20:3385-3393

21. Morgan DO, Roth RA (1986) Mapping surface structures of the human insulin receptor with monoclonal antibodies: localization of main immunogenic regions to the receptor kinase domain. Biochemistry 25: 1364-1371

22. Pilch PF, Czech MP (1980) The subunit structure of the high affinity insulin receptor. Evidence for a disulfide-linked receptor complex in fat cells and liver plasma membranes. $J$ Biol Chem 255: 1722-1731

23. Johnson JD, Wong ML, Rutter WJ (1988) Properties of the insulin receptor ectodomain. Proc Natl Acad Sci 85: 7516-7520

24. Ellis L, Clauser E, Morgan DO, Edery M, Roth RA, Rutter WJ (1986) Replacement of insulin receptor tyrosine residues 1162 and 1163 compromises insulin-stimulated kinase activity and uptake of 2-deoxyglucose. Cell 45: 721-732

25. Ebina Y, Araki E, Taira M et al. (1987) Replacement of lysine residue 1030 in the putative ATP-binding region of the insulin receptor abolishes insulin- and antibody-stimulated glucose uptake and receptor kinase activity. Proc Natl Acad Sci 84: 704-708

26. Chou CK, Dull TJ, Russell DS, Gherzi R, Lebwohl D, Ullrich A, Rosen OM (1987) Human insulin receptors mutated at the ATPbinding site lack protein tyrosine kinase activity and fail to mediate postreceptor effects of insulin. J Biol Chem 262: 1842-1847

27. Morgan DO, Roth RA (1987) Acute insulin action requires insulin receptor kinase activity: introduction of an inhibitory monoclonal antibody into mammalian cells blocks the rapid effect of insulin. Proc Natl Acad Sci 84: 41-45

28. Maassen JA, Klinkhamer MP, Zon GCM van der et al. (1988) Fibroblasts from a leprechaun patient have defects in insulin binding and insulin receptor autophosphorylation. Diabetologia 31: $612-617$

29. Deprez RHL, Loon BJP van, Zon GCM van der et al. (1989) Individuals with only one allele for a functional insulin receptor have a tendency to hyperinsulinaemia but not to hyperglycaemia. Diabetologia 32:740-744

Received: 18 December 1989

and in revised form: 3 April 1990

\section{Dr. H. Makino}

Second Department of Internal Medicine

Chiba University School of Medicine

1-8-1 Inohana, Chiba 280

Japan 